\title{
To Juxtapose is to Metamorphose: Angela Carter`s The Passion of New Eve and Nights at the Circus
}

\author{
Shima Sadat Mirmusa \\ Department of Studies in English University of Mysore, India
}

\begin{abstract}
Carter's idiosyncratic writing aims to challenge the cultural preconceptions of the society and to attack the conventional lines of thought. Through subversion of the inequalities, indeed, she indicates how the boundaries of fixed categories become easily vulnerable. In doing so, she makes use of the device of metamorphosis through which she functions to intertwine the binary oppositions, mainly male/female and fact/fiction dichotomies. In order to explore Carter's treatment of metamorphoses, two very significant and peculiar elements will be discussed in the paper regarding the causality of the transformation in two of her later novels, The Passion of New Eve and Nights at the Circus, that is, the form and the cause of transformation.
\end{abstract}

Key Words: male/female, metamorphosis, opposition, subvert

\section{Introduction}

The paper examines Carter`s treatment of metamorphosis from a new angle which has rarely been dealt with by the critics. To do this, two major points should be brought to attention: first, to what extent Carter`s practice of metamorphosis fulfills her purpose of merging as well as subverting the oppositions, and secondly, which borderlines she transgresses through the act of transformation.

Unlike most of the other literary metamorphoses, Carter`s unique treatment of the subject permeating into her late 70s and 80s novels, The Passion of the New Eve and Nights at the Circus, is not far from the sense of realism. For example, the extreme form of transformation happening in Kafka`s The Metamorphosis, the masterpiece which is more or less compared to Carter`s fiction, is based on the impossibilities in the extratextual world. Gregor Samsa, the protagonist, turns into a non-human, an insect, over the night for no good reason at all (1). However, Carter treats thoroughly in an opposite fashion. Rather than changing the subjects of her metamorphosis into non-human creatures, she transforms them into physically/mentally different but ordinary human beings during a long-running process. Moreover, regardless of the matter-of-fact manner of narration which causes the reader to accept the textual metamorphosis as a real phenomenon, the metamorphosis occurring in her novels is not, per se, beyond the bounds of possibility evoking a world that might be experienced outside the novel. Evelyn, the protagonist of The Passion of the New Eve, for instance, undergoes a sex-change operation which is a quite realistic and possible act per se outside of the textual world, though not very common. Textually speaking, the operation is given a sense of real use of scalpel and other medical instruments in a laboratory similar to the womb: "everything in the room had a curiously artificial quality, though nothing seemed unreal, far from it; Beulah... has an unimpeachable quality of realism. But it is a triumph of science ..." (49). In Nights at the Circus, the real possibility of the transformation is even to a greater extent; Walser, an out-and-out rationalist is converted into an irrational shaman being able to summon the spirits.

\section{Form of Metamorphosis}

The transformations Carter deploys in The Passion of New Eve and Nights at the Circus are associated with both physical and non-physical changes suggesting her feministic and irrationalistic approach, respectively. In The Passion of New Eve, she attempts to physically metamorphose her male protagonist, Evelyn, into a female character, Eve. During his long journey to New York in search of his beloved movie star, Tristessa, Evelyn is captured and taken to Beulah, where he is subjected to a great sexual change by a holy Mother called the "Grand emasculator" (49). While weakening the masculine dominancy of Evelyn through castration and transfiguring him into a female figure, Mother constructs "a perfect archetype" (173). Anatomically, she transforms each and every part of Evelyn`s body into feminine physique so that he can even menstruate, ovulate and bear a child while mentally remaining a man. Since his culturally constructed gender identity is deconstructed by Mother, Evelyn, or the newly constructed Eve, eventually becomes neither a complete man, nor a complete woman. As s/he says, "[Mother] transform[ed] my I into the other and, in doing so, annihilate[d] it" (59). Even, Evelyn himself wonders whether the sexual change he is about to undergo will also transform his masculine nature or he will have to remain on his true gender changing only anatomically into a woman: "Does a change in the coloration of the rind alter the taste of a fruit?" (68). Setting his physical transformation apart, 
Evelyn/Eve is also psychologically confused about his/her duality of nature saying that "at this time, I was literally in two minds; my transformation was both perfect and imperfect. All of new Eve`s experience came through two channels of sensation, her own fleshly ones and his mental ones" (77-78). Elsewhere, Evelyn/Eve considers him/herself as complete genderless: "I know nothing. I am a tabula erasa, a blank sheet of paper, an unhatched egg. I have not yet become a woman, although I possess a woman`s shape. Not a woman, no; both more and less than a real woman" (83).

Therefore, Evelyn`s/Eve`s transformation contributes, to a large degree, to the theme of juxtaposing the both sides of the man/woman binary opposition and reveals that "gender is a meaningless, socially imposed category" (Blodgett 51). Accordingly, as to the Evelyn`s/Eve`s place of transformation, "the place where contraries exist together" (48), Nicoletta Vallorani claims that "juxtaposition is confirmed as a method of disrupting and subverting traditional semantic borders and the conflict is made more evident by the intrinsic nature of the terms place side by side: technology and mythology stand for male and female, respectively" (373). Furthermore, it is noteworthy that the name Evelyn itself is of ambiguous gender denominated to both males and females. Intentionally choosing this name, Carter aims to evoke the capacity and the capability in the human beings ' psyche to let them enjoy the fantasies of their opposite genders. However, the narrative does not remain on the surface of a mere bisexual name, but, as discussed above, it goes further to function as a literal sexual transformation to reach this androgyny.

From this transformation, Evelyn/Eve, physically a woman and psychologically a man, escapes from the women`s society and makes a start on another journey. He/she joins a patriarchal community and falls into the hands of the misogynist Zero, a cruel one-eyed one-legged man who accompanies him/her in search of Tristessa. Unlike Beulah, a strongly women`s society, Zero`s farm is a place of total patriarchy. Considering Beulah the feminine side of the male/female binary, Zero's farm represents the masculine side, which is eventually brought to harmony with the other side. Finally, entangling in a series of conflicting events, they succeed to find Tristessa reposing in her glass palace. Evelyn`s/Eve`s ambition is, thus, fulfilled and he/she is set to wed Tristessa, a transvestite, whom once he/she had been enamored with. The union of Evelyn/Eve and Tristessa is of highly significance in that "It was a double wedding-both were the bride, both the groom in this ceremony" (135). The image of their sexual union represents the creation of a perfect androgynous being suggesting a new order in which man and woman are not quite so opposed: "out of these fathomless kisses and our interpenetrating, undifferentiated sex, we had made the great Platonic hermaphrodite together, the whole and perfect being" (148). Through this union, thus, the notion of conflicting binaries is challenged and suspended existing somewhere between genders: "masculine and feminine are correlatives which involve one another. I am sure of that - the quality and its negation are locked in necessity" (150).

Hence, Evelyn`s/Eve`s metamorphosis favorably leads to an affectionate sexual union, and ultimately to fertility and rebirth; inseminating with his/her own sperm, Evelyn/Eve carries a child who represents a hope for recommence, a new beginning with a new order in which the oppositions of all kinds have been brought to some kind of border-crossing harmony. The child delineates a utopian world where man and woman in particular and other binaries in general are quite equal. Finally, along with his/her unborn baby, Evelyn/Eve is committed to the sea to start a new beginning: "we start from our conclusions" (191). Indeed, the journey Evelyn/Eve has already started has no end; through the regression to his/her beginning, a new life is emerging. However, the metamorphosis does not merely affect a single individual to get reborn, but goes much further and causes the whole world to end in order to start a new beginning. The text's reference to the "YEAR ONE" (172) is the representative of such a recommence.

Consequently, through Evelyn`s/Eve`s reconstruction, and the male/female fusion, Carter questions the very sexual category she transgresses and explores, in general, how femininity and masculinity can be artificially constructed rather than been biologically born. Furthermore, she undermines the very European rationalistic and scientific views. The British sensible Evelyn who was once in search of reason and logic in New York and who believed that "All this witchery offended" his "European sensibility" (32), is confronted with the irrationalities of transformation in Beulah.

Much in a dissimilar manner, in Nights at the Circus, Carter is concerned with a non-physical form of metamorphosis; Walser, a man of proof and sensibility, undergoes an inward change becoming a man of irrationalities. In the beginning, he appears as a rational American reporter assigned to interview the worldfamous winged-woman aerialist Fevvers. Since his strong scientific principles fail him to believe in Fevvers as a bird-woman creature, he tries hard to find any document proving the credibility of her claims and the fantastic events she describes during the interview. However, the more he is presented with documents as proofs of such improbabilities, the more he is baffled and made to contemplate. His lopsided reflection on the physical structure of Fevvers' body suggests the very opposition he takes into account between fact and fiction (Magali Cornier 4). Right in the beginning, he ponders the way the wings from beneath her dressing-gown were "shuddering the surface of the taut fabric from time to time as if desirous of breaking loose" (8) and while 
watching her performance, he "contemplate[s] the unimaginable" and identifies a "paradox": "in a secular age, an authentic miracle must purport to be a hoax, in order to gain credit in the world" (17).

The notions of reason and sensibility are discredited when Walser, a rational interviewer, is degraded and humiliated by Fevvers, a fantastic, irrational and perhaps hallucinatory creature: "no woman ever tried to humiliate him before, to his knowledge, and Fevvers has both tried and succeeded" (145). In the sense of profession, Carter represents Walser, an educated young man, to have "no special skills to offer, could not walk the high-wire, would have ridden a zebra like a sailor on horseback" (101). He is eventually "hired cheaply" to make a fool of himself as a clown whereas Fevvers, a fantastic winged-creature woman, does not have the slightest problem regarding employment. However, through Walser`s metamorphosis which endows him not only with physical but also with metaphysical power, Carter`s practice of overturning the reason/unreason opposition is fulfilled representing the victory of irrationality over the rationality.

At last, Walser, who believed that Fevvers "by all the laws of evolution and human reason, ought to possess no arms at all, for it`s her arms that ought to be her wings" (15), undergoes a thorough mental change. Being hit on the head by falling debris resulting from the derailment of the travelling circus train in Siberia, he loses his consciousness which represents his symbolic rebirth. His childish and naïve behavior, "flapping his arms up and down" and singing "Cock-a-doodle-do! Cock-a-doodle-dooski!" (224), for example, suggest that he has turned into "a perfect blank" (222) baby the result of which is the loss of his entire sense of rationality: "He is a sentient being, still, but no longer a rational one; indeed, now he is all sensibility, without a grain of sense, and sense impressions alone have the power to shock and to ravish him. In his elevated state, he harkens to the rhythm of the drum" (236).

Suffering from the amnesia, Wasler accidently steps into a fantastic indigenous tribe where there is "no difference between fact and fiction; instead, a sort of magic realism" (260). There, he meets a shaman whose task is "the interpretation of the visible world about him via the information he acquire[s] through dreaming" (253). Starting his apprenticeship to become a shaman, he must undergo a gradual mental transformation, and to reach this metaphysical change, yet, surprisingly enough, he has to bear some physical sufferings. Following the rituals of the tribe, the entire shamans of the village "fired arrows at him from their bows until he went off into another fainting fit within the fainting fit... cut him up in pieces and ate him raw. They counted the bones that were left ... they put them back together again and restored the boy with a strengthening drink of reindeer blood" (255). This fundamental metamorphosis, like Evelyn`s change, leads to a joyful union coupling Wasler with Fevvers. Having experienced the hallucinatory world of the shamans, Walser, previously a verifier of fact, is now unable to distinguish between fact and fiction and is ready to believe fully in Fevvers and her stories rather than trying to adjust them within his cultural and rational framework. Fact or fiction is no longer his issue of interest or obsession as he remains indifferent to the fact that "she [Fevvers] indeed appeared to possess no navel" (292). The very long beard he has grown within a short period of time, astonishes Fevvers as though Walser is endowed with a unique magical skill to play with time and make it standstill. Fevvers` foster mother directly states that "by the length of Mr. Walser's beard and the skill with which he rode his reindeer, time has passed - or else is passing - marvelous swiftly for those woodland folk" (272). This incongruity and trickery in the time span conjured skillfully by Walser not only threatens to transgress the western temporal laws but also overturns the reason/unreason opposition representing the irrational Walser in the position of full authority. Moreover, Walser who used to be downgraded due to his strong belief in rationalities, is now given too much attention by Fevvers. She believes "surely he [Walser] will have the decency to give himself to me... let him hand himself over into my safekeeping ... I'll sit on him, I'll hatch him out, I'll make a new man of him. I'll make him into the New Man, in fact, fitting mate for the New Woman, and onward we'll march hand in hand into the New Century" (281). As discussed, Walser is metamorphosed at three phases each driving him toward the perfection; first he is presented as a baby, then as an irrational shaman, and finally as a New Man who together with Fevvers enters a New Century. Therefore, the sense of rebirth, togetherness and, in a comprehensive sense, beginning of a new world serve as the points of similarities between the two novels though the act of metamorphosis, per se, tends to be a significant element of contrast.

As the aforementioned study of the novels proves, Carter`s specific use of metamorphosis paves the way to manifest the equality between male/female as well as fact/fiction dichotomies. She aims to juxtapose these extremes alongside one another with no preference. The novels reveal that there is no complete destabilization of any side of the fact/fiction or male/female binaries. Neither fact (man) nor fiction (woman) is sufficient per se; they are both required to make one other complete. This will dovetail well into Brian H. Finney`s assertion that what is less "typical is Carter's resistance to endorsing either fact or fiction in isolation. Each world is dependent on and incorporates the other. Fiction feeds on facts and facts on fiction" (13). The same is treated with the male/female dichotomy. 


\section{Cause of Metamorphosis}

The causal element is the next important aspect in Carter`s practice of metamorphosis which unlike the former one is a point of similarity between the novels. The journeys Evelyn/Eve and Walser start are welltrodden towards the change by the presence of some powerful feministic forces which directly or indirectly help them to unwillingly accomplish the task of transformation. To put it another way, Evelyn/Eve and Walser serve as jumping jacks whose strings are moved by some influential images. These driving forces behind the project of metamorphosis are their counterparts, Leilah and Fevvers. Leilah is a black prostitute Evelyn meets in the beginning of his journey arousing his most savage desires. Evelyn`s further cruel treatment of Leilah, tying her to the bed, beating her, and leaving her pregnant, becomes the cause of his sufferings and humiliations during the transformation: "let the punishment fit the crime, whatever it had been. They had turned me into the playboy center fold. I was the object of all the unfocused desires that have ever existed in my own head" (75). In fact, it is all Leilah`s arrangement to take Evelyn "deep into the geometric labyrinth of the heart if the city" (21), then into her "lightless" apartment, and finally to the desert under the Mother`s hands causing him to be enchanted by her sexual eroticism:

When Leilah lured me out of the drug store, into the night, towards her bed, she had organized the conspiracy of events that involved the desert, the dead bird, the knife, the sacrificial stone. Leilah had lured me here, at last; Leilah had always intended to bring me here, to the deepest cave, to this focus of all the darkness that had always been waiting for me in a room with just such close, red walls within me. (58)

Through this painful transformation, Leilah, as one of its causal elements, aims to represent the authority of women to provide the counter-gender with a perfect change and to subvert the conventional notion of suffering females dominated by males. Indirectly driving Evelyn toward the change, Leilah leaves the rest of the task to her holy Mother. Physically involved in Evelyn`s transformation, Mother, who herself enjoys a fusion of opposites, natural/unnatural and mundane/spiritual, goes well on the business of merging masculinity and femininity.

By comparison, in Nights at the Circus, Walser is psychologically transformed under a feminine power, Fevvers, whom he finally units with. Acting as a driving force, Fevvers unconsciously pulls Walser towards herself into the circus arena entangling him in the train crash which causes him to lose his consciousness and enter the shamans' village where he ultimately undergoes the transformation. This is very neatly indicated in Walser's own remark: "Jack ... ran away with the circus for the sake of a bottle blonde in whose hands he was putty since the first moment he saw her ... all that seemed to happen to me in the third person as though, most of my life, I watched it but did not live it" (294). If "Walser is like clay that can still be moulded" and a "feasible material to work with" (Servranckx 35), it will be Fevvers who can successfully mould and reconstruct him thoroughly similar to her own self, and make an alter ego of herself. Since she is not fully satisfied with Walser`s initial metamorphosis, she continues to consciously transform him to a greater extent: "let him hand himself over into my safekeeping, and I will transform him ... I'll make a new man of him. I'll make him into the New Man, in fact, fitting mate for the New Woman" (281). Therefore, although the two narratives vary widely in terms of dealing with the form of metamorphosis, they enjoy similar cause of transformation.

\section{Conclusion}

In sum, there is a double action at work in Carter`s use of metamorphosis, to merge and, to a lesser degree, to subvert. Standing against the dictates of the society that evaluates human beings in terms of gender, rationality, and any other traditionally accepted notions, Carter tends to juxtapose the apparently opposite ideas bringing them side by side with one another. Moreover, Carter transgresses the bounds of the Western logic such as the biological construction, the temporal fluidity, as well as the positivist approach while representing the artificial construction, the illogical flow of time, and irrationality as the distinct possibilities of the nature. To fulfill such purposes, she takes the advantage of a magnificent device: metamorphosis.

\section{References}

\section{Journal Papers:}

[1]. H. Blodgett, Fresh Iconography: Subversive Fantasy by Angela Carter, Review of Contemporary Fiction, 14(3), 1994, 49-55.

[2]. N. Vallorani, The Body of the City: Angela Carter`s The Passion of the New Eve, Science Fiction Studies, 21(3), 1994, 365-379.

[3]. M. C. Magali, Fantasy and Carnivalization in Angela Carter`s Nights at the Circus, Feminism and the Postmodern Impulse: Post-World War II Fiction, 1996, 171-208.

[4]. H. B. Finney, Tall Tales and Brief Lives: Angela Carter`s Nights at the Circus, Journal of Narrative Technique, 28(2), 1998, $161-85$.

\section{Books:}

[5]. A. Carter, The Passion of New Eve (London: Arrow Books, 1977).

[6]. A. Carter, Nights at the Circus (London: Vintage, 1984)

[7]. F. Kafka, Metamorphosis. Trans. Willa and Edwin Muir. Metamorphosis and Other Stories (Middlesex: Penguin, 1961) Theses:

[8]. P.Servranckx,Deconstructing Patriarchal Society through Literature: Angela Carter and the 'Demythologising Business', doctoral diss., University of Gent, 2009. 